\title{
Inappropriate expression of blood group antigens on biliary and colonic epithelia in primary sclerosing cholangitis
}

\author{
S Bloom, A Heryet, K Fleming, R W Chapman
}

\begin{abstract}
The distribution of carbohydrate antigens of the ABO, Lewis, and Kell systems was examined in biliary and colonic epithelial of 11 patients with primary sclerosing cholangitis (PSC) using a panel of 11 monoclonal antibodies. Controls consisted of 27 liver biopsy specimens (11 normal, six alcoholic liver disease, five extrahepatic obstruction, and five primary biliary cirrhosis) and 24 colonic biopsy specimens (six normal, four Crohn's disease, and 14 ulcerative colitis). There was inappropriate staining with anti-A (four of six, $66 \%$ ) and anti-B (nine of $11,81 \%$ ) in biliary epithelium of PSC patients compared with normal and disease controls. Expression of Lewis antigens was increased in patients with cholestatic liver disease. Ninety one per cent of PSC patients showed a similar pattern of inappropriate staining by anti-A and anti-B antibodies in colonic epithelium compared with $33 \%$ of normal and $42 \%$ of inflammatory bowel disease controls. There is inappropriate expression of $A$ and $B$ carbohydrate antigens in biliary and colonic epithelium in PSC. Whether these oncofetal antigens are implicated in the pathogenesis of this condition is discussed. (Gut 1993; 34: 977-983)
\end{abstract}

Primary sclerosing cholangitis (PSC) is a chronic cholestatic liver disease that often progresses to cirrhosis and death from liver failure or cholangiocarcinoma. ${ }^{12}$ The aetiology is unknown but evidence suggests that immunological mechanisms may be important in the pathogenesis. There is an association with the HLA-B8-DR3 haplotype, which is associated with other organ specific autoimmune diseases. ${ }^{34}$ In PSC, abnormalities in lymphocyte subsets exist in peripheral blood, ${ }^{5}$ there is enhanced autoreactivity of suppressor/cytotoxic $T$ cells from peripheral blood to class II major histocompatibility antigens, ${ }^{6}$ and aberrant expression of class II anti-

TABLE I Clinical details of study subjects

\begin{tabular}{|c|c|c|c|c|c|}
\hline Diagnosis & No & $\begin{array}{l}\text { Sex } \\
(M: F)\end{array}$ & $\begin{array}{l}\text { Age (mean } \\
(\text { range) })(y)\end{array}$ & $\begin{array}{l}\text { Bilirubin } \\
(\text { mean }(\text { range })) \\
(\mu \text { molll })\end{array}$ & $\begin{array}{l}\text { Alkaline } \\
\text { phosphatase } \\
\text { (mean (range)) } \\
(I U / l)\end{array}$ \\
\hline $\begin{array}{l}\text { Normal } \\
\text { Alcoholic liver disease } \\
\text { Extrahepatic obstruction } \\
\text { Primary biliary cirrhosis } \\
\text { Primary sclerosing cholangitis } \\
\text { Stage } 1 \\
\text { Stage } 2 \\
\text { Stage } 3 \\
\text { Stage } 4\end{array}$ & $\begin{array}{r}5 \\
6 \\
5 \\
5 \\
11 \\
2 \\
3 \\
4 \\
2\end{array}$ & $\begin{array}{l}2: 3 \\
4: 2 \\
4: 1 \\
0: 5 \\
8: 3\end{array}$ & $\begin{array}{l}59(23-79) \\
58(49-68) \\
60(43-80) \\
55(46-67) \\
47(21-80)\end{array}$ & $\begin{array}{l}8 \cdot 6(3-20) \\
20 \cdot 3(9-55) \\
66 \cdot 2(12-141) \\
49 \cdot 3(11-147) \\
14 \cdot 6(5-35) \\
12 \\
19 \cdot 7 \\
8 \cdot 7 \\
18 \cdot 5\end{array}$ & $\begin{array}{l}608(222-1319) \\
361(181-520) \\
545(208-995) \\
940(431-1302) \\
1390(402-4365) \\
951 \\
993 \\
1420 \\
2384\end{array}$ \\
\hline
\end{tabular}

gens on biliary epithelium has been found. Activated $T$ cells have been shown to be associated with bile duct destruction. ${ }^{8}$ Abnormalities in humoral immunity, include circulating immune complexes, reduced clearance of immune complexes, and increased complement metabolism have been detected. ${ }^{9-11}$ Further evidence of immune mediation has come from the finding of circulating, non-organ specific and organ specific antibodies. ${ }^{12} 13$

PSC is associated with inflammatory bowel disease in between 50 and $75 \%$ of cases. ${ }^{14}$ It has been established that the characteristic pattern of expression of certain carbohydrate antigens, including those of the $\mathrm{ABO}$ and Lewis systems, is altered in bowel neoplasms, ${ }^{15} 16$ and similar abnormalities have also been shown in ulcerative colitis. ${ }^{17}$ There has recently been interest in the pattern of distribution of these antigens in the biliary epithelium in both normal ${ }^{18}$ and diseased livers. ${ }^{19}$ The differential expression of these antigens in the biliary tree, coupled with the known change in their pattern of expression in inflammatory bowel disease, led us to investigate their expression in the biliary and colonic mucosa of patients with PSC. Since changes in blood group antigen expression in the colon are associated with dysplasia and may be useful in screening for the development of colorectal carcinoma, we were particularly interested to look for a similar association between inappropriate expression of blood group antigens in the biliary tree and biliary dysplasia and cholangiocarcinoma.

\section{Patients and methods}

Thirty eight liver biopsy specimens were examined using a panel of 11 monoclonal antibodies raised against carbohydrate antigens of the $\mathrm{ABO}$, Lewis and Kell blood groups. Eleven patients with PSC were studied. All had ulcerative colitis that affected the whole colon. The diagnosis of PSC was established by standard criteria - that is, by persistently abnormal liver enzyme activities, liver histology, and ERCP changes. ${ }^{12}$ The histological grading of the PSC biopsy specimens is shown in Table I. Controls included five normal biopsy specimens, six specimens showing alcoholic liver disease, five extrahepatic obstruction, and five primary biliary cirrhosis. Clinical details are given in Table I.

Formalin fixed, wax embedded sections were deparaffinised and rehydrated in xylene and ethanol. The monoclonal antibodies were applied by a three stage indirect immunoperoxidase technique described elsewhere. ${ }^{20}$ The 
TABLE II Provenance and immunoglobulin subclass of monoclonal antibodies

\begin{tabular}{lllll}
\hline Name & Source & Reactivity & Ig class & Titre \\
\hline 17519 & Oxford & Anti-A & IgM & $1: 10$ \\
Bric 175 & Bristol & Anti-A & IgM & $1: 20$ \\
16818-2 & Oxford & Anti-B & IgM & $1: 10$ \\
Bric 86 & Bristol & Anti-B & IgM & $1: 10$ \\
LM 251/525 & Glasgow & Anti-AB & IgM & $1: 5$ \\
Bric 70 & Bristol & Anti-H & IgM & $1: 5$ \\
LM 92/94 & Glasgow & Anti-H & IgM & $1: 1$ \\
Bric 87 & Bristol & Anti-Lea & IgM & $1: 20$ \\
LM 112/116 & Glasgow & Anti-Lea & IgM & $1: 20$ \\
LM 129/181 & Glasgow & Anti-Leb & IgM & $1: 20$ \\
Bric 68 & Bristol & Anti-Kell & IgG2 & $1: 2$ \\
\hline
\end{tabular}

source, immunoglobulin subclass, and dilution of antibody used are shown in Table II. The dilutions used were those previously established as exhibiting the best ratio of staining to background. Sections were examined and scored 'blind' by two experienced observers, using a scoring system that ranged from negative, through intermediate $( \pm)$, to strongly positive $(+++)$. The distribution of staining (luminal cytoplasmic, focal/general) was also noted. As a further control, an IgG antibody to an unrelated determinant in human liver and colon was used to stain 36 sections of human colon to ensure that there was no non-specific binding of IgG (data not shown). Unrelated IgM antibodies were not used since most of the blood group monoclonal antibodies used are IgM and several gave completely negative staining, making non-specific binding very unlikely.

The expression of the same carbohydrate antigens was then studied in the colonic epithelium of the 11 patients with PSC. All 11 patients

TABLE III Expression of $A, B$, and $H$ antigens on bile ducts $(B D)$ and hepatocytes $(H e p)$

\begin{tabular}{|c|c|c|c|c|c|c|c|}
\hline \multirow[b]{2}{*}{ Group } & & \multicolumn{2}{|l|}{$A$} & \multicolumn{2}{|l|}{$B$} & \multicolumn{2}{|l|}{$H$} \\
\hline & & Hep & $B D$ & Hep & $B D$ & Hep & $B D$ \\
\hline $\operatorname{Normal}(n=11)$ & $\begin{array}{l}\text { A } \\
\text { A } \\
\text { O } \\
\text { O } \\
\text { O } \\
\text { O } \\
\text { A } \\
\text { A } \\
\text { O } \\
\text { O } \\
\text { O }\end{array}$ & $\begin{array}{l} \pm \\
- \\
- \\
\pm \\
- \\
- \\
- \\
- \\
\pm \\
- \\
-\end{array}$ & $\begin{array}{l} \pm \\
- \\
- \\
- \\
- \\
- \\
- \\
- \\
- \\
- \\
-\end{array}$ & $\begin{array}{l} \pm \\
\pm f \\
- \\
\pm \\
- \\
\pm \\
- \\
- \\
\pm \\
- \\
-\end{array}$ & $\begin{array}{l}- \\
- \\
- \\
- \\
- \\
- \\
- \\
- \\
- \\
-\end{array}$ & $\begin{array}{l}- \\
- \\
- \\
- \\
- \\
- \\
+ \\
- \\
+ \\
++ \\
++\end{array}$ & $\begin{array}{l}- \\
- \\
- \\
- \\
- \\
- \\
+ \\
- \\
- \\
+ \\
-\end{array}$ \\
\hline Alcoholic liver disease $(n=6)$ & $\begin{array}{l}\text { A } \\
\text { A } \\
\text { A } \\
\text { O } \\
\text { O } \\
\text { O }\end{array}$ & $\begin{array}{l}- \\
- \\
- \\
- \\
- \\
-\end{array}$ & $\begin{array}{l}- \\
- \\
- \\
\overline{ \pm} \\
-\end{array}$ & $\begin{array}{l}- \\
- \\
- \\
- \\
-\end{array}$ & $\begin{array}{l}- \\
- \\
- \\
- \\
\pm \\
\pm\end{array}$ & $\begin{array}{l}+ \\
+ \\
+ \\
+ \\
++ \\
++\end{array}$ & $\begin{array}{l}- \\
+ \\
+ \\
\pm f \\
++ \\
++\end{array}$ \\
\hline Extrahepatic obstruction $(n=5)$ & $\begin{array}{l}\text { A } \\
\text { A } \\
\text { A } \\
\text { B } \\
\text { B }\end{array}$ & $\begin{array}{l}- \\
- \\
- \\
-\end{array}$ & $\begin{array}{l}- \\
\overline{-} \\
- \\
-\end{array}$ & $\begin{array}{l}- \\
\pm \mathbf{f} \\
- \\
- \\
-\end{array}$ & $\begin{array}{l}- \\
\pm \\
- \\
+ \\
-\end{array}$ & $\begin{array}{l}+ \\
\pm \\
++ \\
++ \\
+\end{array}$ & $\begin{array}{l}- \\
\pm \\
++ \\
++ \\
-\end{array}$ \\
\hline $\begin{array}{l}\text { Primary biliary cirrhosis } \\
(\mathbf{n}=5)\end{array}$ & $\begin{array}{l}\mathrm{AB} \\
\mathrm{O} \\
\mathrm{O} \\
\mathrm{O} \\
\mathrm{O}\end{array}$ & $\begin{array}{l}- \\
\overline{-} \\
\overline{-}\end{array}$ & $\begin{array}{l} \pm \\
- \\
- \\
- \\
-\end{array}$ & $\begin{array}{l} \pm \\
- \\
- \\
- \\
-\end{array}$ & $\begin{array}{l} \pm \\
- \\
- \\
- \\
-\end{array}$ & $\begin{array}{l}+ \\
+ \\
+ \\
\pm \\
++\end{array}$ & $\begin{array}{l}+ \\
+ \\
+ \\
+ \\
\pm\end{array}$ \\
\hline $\begin{array}{l}\text { Primary sclerosing cholangitis } \\
(\mathbf{n}=11)\end{array}$ & $\begin{array}{l}\text { A } \\
\text { A } \\
\text { A } \\
\text { A } \\
\text { A } \\
\text { O } \\
\text { O } \\
\text { O } \\
\text { O } \\
\text { O } \\
\text { O }\end{array}$ & $\begin{array}{l}- \\
- \\
- \\
- \\
- \\
- \\
- \\
+ \\
+ \\
-\end{array}$ & $\begin{array}{l}- \\
- \\
- \\
\pm \\
++ \\
\pm \\
- \\
- \\
\pm \\
\pm \\
+\end{array}$ & $\begin{array}{l}- \\
+ \\
\pm \\
\pm \\
- \\
- \\
\pm \\
+ \\
+ \\
+ \\
+\end{array}$ & $\begin{array}{l}- \\
+ \\
+ \\
\pm \\
\pm \\
+ \\
+ \\
+ \\
+ \\
+ \\
+\end{array}$ & $\begin{array}{l}+ \\
++ \\
+++ \\
\text { NT } \\
\text { NT } \\
+ \\
++ \\
\pm \\
+++ \\
++ \\
++ \\
\text { NT }\end{array}$ & $\begin{array}{l} \pm \\
++ \\
+ \\
\text { NT } \\
\text { NT } \\
+ \\
+ \\
\pm \\
+ \\
+ \\
+ \\
\text { NT }\end{array}$ \\
\hline
\end{tabular}

$\mathrm{NT}=$ not tested. $\mathrm{f}=$ focal had ulcerative colitis diagnosed on clinical and colonoscopic criteria, with inflammation affecting the whole colon in all. For this part of the study controls comprised six normal colonic biopsy specimens and 18 biopsy specimens from inflammatory bowel disease patients (14 with ulcerative colitis and four with Crohn's disease). Liver function tests were persistently normal in controls, and they were therefore presumed not to have PSC. ERCP was not performed in these patients.

\section{NEURAMINIDASE TREATMENT}

Sections from five patients that were found to show inappropriate expression of blood group antigens in liver and colon were treated with neuraminidase using established protocols ${ }^{21-23}$ in an attempt to see whether digestion of sialic acid residues would abolish staining.

\section{STATISTICAL ANALYSIS}

Mean bilirubin and alkaline phosphatase values in PSC patients and both normal and disease controls were compared using the MannWhitney $U$ test for non-parametric data.

\section{Results}

\section{LIVER HISTOLOGY}

Tables III and IV show the distribution of staining with anti-ABH and Lewis antibodies in biliary epithelia and hepatocytes in 38 liver biopsy specimens. Inappropriate expression of A and $B$ antigens was observed in specimens from PSC patients compared with normal liver biopsy specimens and tissues from other disease groups. In particular, four of six (66\%) blood group $\mathrm{O}$ patients showed evidence of inappropriate biliary expression of A antigen (Fig $1(\mathrm{~A})$ ). Two of these also showed some (graded +) staining of hepatocytes. Nine of $11(81 \%)$ PSC patients showed inappropriate biliary expression of blood group B antigen, seven being graded as + and two as \pm (Fig $1(B)$ ). Seven of this group also showed some staining in hepatocytes: four were graded as + and three as \pm . The biliary staining was diffuse and cytoplasmic and involved small and large bile ducts in all portal tracts. In 27 normal and disease control biopsy specimens, one $(3 \cdot 7 \%)$ showed very weak inappropriate biliary staining by anti-A antibodies and three (11\%) by anti-B antibodies (Table III). There was no significant difference between PSC and control groups in the frequency of blood groups $(\mathrm{O}, 45 \%$ v 37\%; $\mathrm{A}, 54 \%$ v $51 \%)$ or in liver function tests undertaken at the time of liver biopsy.

In the 27 normal and disease control biopsy specimens, three $(11 \cdot 1 \%$; one group $A$, two group $\mathrm{O}$ ) showed (very weak) staining of hepatocytes with anti-A antibody and six $(22 \%$; three group $\mathrm{A}$, two group $\mathrm{O}$, one group $\mathrm{AB}$ ), showed (weak) staining with anti-B, which was focal in two of the cases. By contrast, hepatocytes in 28 of 35 specimens $(80 \%)$ and biliary cells in 21 of 35 $(60 \%)$ showed positive staining with anti-H antibody. There was little difference in the 
TABLE IV Expression of Lewis $a$ and $b$ antigens in bile duct epithelium

\begin{tabular}{|c|c|c|c|c|}
\hline Group & $\begin{array}{l}\text { Blood } \\
\text { group }\end{array}$ & $\begin{array}{l}\text { Lewis } \\
a\end{array}$ & ${ }_{b}^{\text {Lewis }}$ & Distribution \\
\hline $\operatorname{Normal}(n=11)$ & $\begin{array}{l}\text { A } \\
\text { A } \\
\text { O } \\
\text { O } \\
\text { O } \\
\text { O } \\
\text { A } \\
\text { A } \\
\text { O } \\
\text { O } \\
\text { O }\end{array}$ & $\begin{array}{l}++ \\
+ \\
+ \\
++ \\
++ \\
++ \\
+ \\
+ \\
\pm \\
+ \\
+\end{array}$ & $\begin{array}{l}++ \\
+ \\
++ \\
++ \\
+ \\
+ \\
+ \\
+ \\
\pm \\
+ \\
\pm\end{array}$ & Luminal \\
\hline $\begin{array}{l}\text { Alcoholic liver disease } \\
(n=6)\end{array}$ & $\begin{array}{l}\text { A } \\
\text { A } \\
\text { A } \\
\text { O } \\
\text { O } \\
\text { O }\end{array}$ & $\begin{array}{l}- \\
- \\
+ \\
+ \\
+ \\
+\end{array}$ & $\begin{array}{l}- \\
- \\
+ \\
\text { NT } \\
+ \\
+\end{array}$ & Luminal \\
\hline $\begin{array}{l}\text { Extrahepatic } \\
\quad \text { obstruction }(n=5)\end{array}$ & $\begin{array}{l}\text { A } \\
\text { A } \\
\text { A } \\
\text { B } \\
\text { B }\end{array}$ & $\begin{array}{l}+ \\
+ \\
+ \\
++ \\
++\end{array}$ & $\begin{array}{l}+ \\
++ \\
++ \\
++ \\
++\end{array}$ & Cytoplasmic \\
\hline $\begin{array}{l}\text { Primary biliary } \\
\quad \text { cirrhosis }(n=5)\end{array}$ & $\begin{array}{l}\mathrm{AB} \\
\mathrm{O} \\
\mathrm{O} \\
\mathrm{O} \\
\mathrm{O}\end{array}$ & $\begin{array}{l}++ \\
\pm \\
+ \\
- \\
++\end{array}$ & $\begin{array}{l}++ \\
++ \\
++ \\
\pm \\
++\end{array}$ & Cytoplasmic \\
\hline $\begin{array}{l}\text { Primary sclerosing } \\
\text { cholangitis }(n=11)\end{array}$ & $\begin{array}{l}\text { A } \\
\text { A } \\
\text { A } \\
\text { A } \\
\text { A } \\
\text { O } \\
\text { O } \\
\text { O } \\
\text { O } \\
\text { O } \\
\text { O }\end{array}$ & $\begin{array}{l}++ \\
+ \\
+ \\
+ \\
+ \\
++ \\
++ \\
++ \\
+ \\
+ \\
++\end{array}$ & $\begin{array}{l}++ \\
+ \\
+ \\
++ \\
+++ \\
+++ \\
++ \\
++ \\
++ \\
++ \\
+++\end{array}$ & Cytoplasmic \\
\hline
\end{tabular}

NT= not tested.

intensity of staining of hepatocytes compared with biliary cells with anti-H antibody except in the PSC group where staining was most intense in the hepatocytes.

Table IV shows the result of staining with antiLewis antibodies. Biopsy specimens from cholestatic disease groups (that is, extrahepatic obstruction, primary biliary cirrhosis, and PSC) tended to show stronger expression of Lewis antigens, and especially of Lewis $b$, than specimens from normal or alcoholic patients. In specimens from normal or alcoholic patients, expression of Lewis antigens was mainly in small bile ducts and showed a predominantly luminal pattern, while in the cholestatic disease groups, expression was mainly cytoplasmic and was seen in small and large ducts (Fig l(C) and (D)).

\section{COLONIC HISTOLOGY}

Table $\mathrm{V}$ shows the results of staining of colonic biopsy specimens with the same monoclonal antibodies in the 11 PSC patients. The five blood group A patients show the normal pattern of expression of the $A$ antigen in the proximal colon but loss distal to the splenic flexure. The six group $\mathrm{O}$ patients all show a consistent pattern of inappropriate staining with anti-A (Fig 2(A)). This is graded as + in five (focal in two) and \pm in one. Ten of 11 PSC patients show inappropriate staining with anti-B antibody (Fig 2(B). This was consistently graded + in all six group $O$ patients, but was focal in three of the four positive group $A$ patients. The two patients in whom $B$ antigen was not expressed in the biliary epithelium showed B antigen in colonic epithelium, although this was focal in only one.

Lewis a antigen was expressed uniformly throughout the colon. The expression of Lewis $b$ in the colon was weaker than that observed in the biliary epithelium in almost all patients.

In the normal colonic biopsy specimens $(n=$ 6), two patients showed inappropriate staining (graded as +) with anti-B antibodies. Both patients were blood group $\mathrm{O}$. These patients also showed some staining with anti-A antibodies (one was graded + and one \pm ). $\mathrm{H}$ antigen was expressed to a varying degree in all biopsy specimens but was weaker in the distal colon. Lewis a was expressed throughout the colon but expression of Lewis $b$ was less noticeable in the distal colon (Table VI).

Control colonic biopsy specimens were also taken from 18 patients with inflammatory bowel disease (14 with ulcerative colitis and four Crohn's disease). Six of the 14 with ulcerative colitis (three from group A and three group $\mathrm{O}$ ) showed some evidence of inappropriate B antigen expression, but in three of these expression was focal, and in another dysplasia was present. In a fifth, B antigen was expressed strongly in the descending colon, but only weakly in the splenic flexure and the sigmoid colon which suggests that it might have been artefactual. Of the six ulcerative colitis patients who showed inappropriate staining to anti-B, the three with blood group $\mathrm{O}$ also showed some positivity to anti-A, although this was only focal. One of four patients with Crohn's disease showed inappropriate B antigen expression as well as inappropriate A antigen expression: in both cases the expression was focal. Lewis a expression was seen throughout the colon, while Lewis b was expressed more strongly in the proximal than distal colon.

Inappropriate staining with antibodies to blood group antigens was therefore seen in the colonic mucosa of 10 of $11(91 \%)$ of PSC patients and in two of six (33\%) normal controls and seven of $18(42 \%)$ of disease controls.

\section{NEURAMINIDASE TREATMENT}

Treatment of tissue sections with neuraminidase had no significant effect on the expression of Lewis or $\mathrm{ABO}$ antigens in the liver or colon.

\section{Discussion}

These results show that there is inappropriate staining by antibodies to blood group antigens in the biliary epithelium of most PSC patients compared with normal and disease controls, and that similar inappropriate staining is seen in the colonic epithelium. In colonic biopsy specimens from normal and colitic controls inappropriate staining is less evident.

Expression of both $\mathrm{ABH}$ and Lewis antigens in normal bile ducts, but Lewis antigens only in the smaller bile ductules has been described previously. ${ }^{18}$ In both chronic and alcoholic hepatitis there is not only a quantitative change in proliferating bile ductules, with both Lewis antigens more strongly expressed, but also a qualitative change with expression of a sialylated form of the antigen that is not seen in normal 

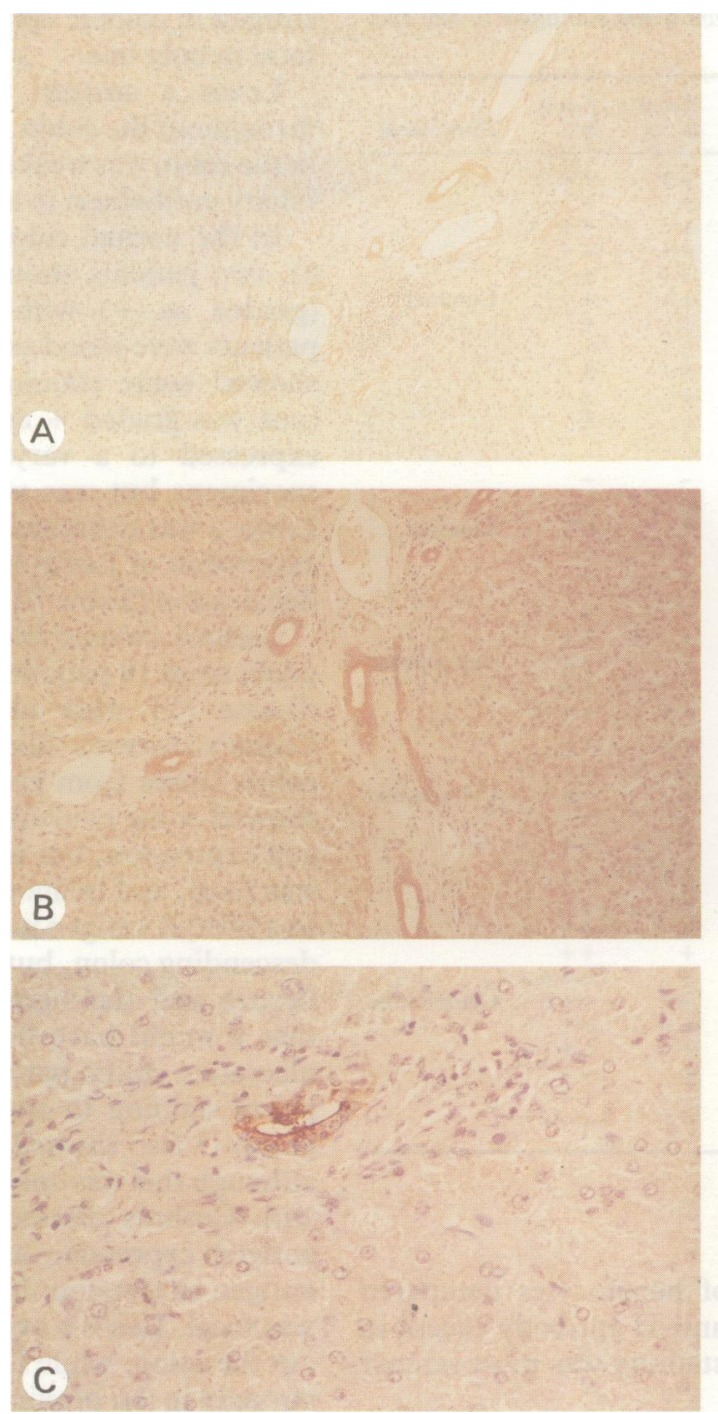

ductules. ${ }^{19}$ We found little staining with anti-A antibodies in the biliary epithelium of the normal and disease control groups, although the $\mathrm{H}$ antibodies stained the biliary epithelium well. We also saw appreciable hepatocyte staining with the anti-H antibody (Table VI) which has

TABLE V Staining of colonic mucosa of primary sclerosing cholangitis patients

\begin{tabular}{|c|c|c|c|c|c|c|}
\hline \multirow{2}{*}{$\begin{array}{l}\text { Blood } \\
\text { group }\end{array}$} & \multirow[b]{2}{*}{ Site } & \multicolumn{5}{|l|}{ Antibody staining } \\
\hline & & $A$ & $B$ & $H$ & $L e^{\mathbf{a}}$ & $L e^{\mathrm{b}}$ \\
\hline \multirow[t]{2}{*}{ A } & Liver & - & - & $+\mathrm{Hep}, \pm \mathrm{BD}$ & ++ & ++ \\
\hline & Colon & Focal & Focal & NT & + & + \\
\hline \multirow[t]{2}{*}{ A } & Liver & - & + Hep, BD & ++ Hep, BD & + & + \\
\hline & Colon & $+\mathrm{HF}$ & + Focal HF & NT & + & + \\
\hline \multirow[t]{2}{*}{ A } & Liver & - & \pm Hep, + BD & $+++\mathrm{Hep},+\mathrm{BD}$ & + & + \\
\hline & Colon & + & $+\mathrm{AC}$ & NT & + & + \\
\hline \multirow[t]{2}{*}{ A } & Liver & - Hep, \pm BD & \pm Hep, BD & NT & + & ++ \\
\hline & Colon & \pm HF, - Distal & +Focal & NT & + & + \\
\hline \multirow[t]{2}{*}{ A } & Liver & $-\mathrm{Hep},++\mathrm{BD}$ & - Hep, \pm BD & NT & + & +++ \\
\hline & $\begin{array}{l}\text { Colon } \\
\text { Liver }\end{array}$ & $\stackrel{+}{-\mathrm{Hep}, \pm \mathrm{BD}}$ & $\begin{array}{l}- \\
-\mathrm{Hep},+\mathrm{BD}\end{array}$ & $\begin{array}{l}\text { NT } \\
+ \text { Hep, BD }\end{array}$ & $\begin{array}{l}+ \\
++\end{array}$ & $\begin{array}{l}+ \\
+++\end{array}$ \\
\hline $\mathrm{O}$ & Colon & + & & NT & $\begin{array}{l}++ \\
++\end{array}$ & + \\
\hline \multirow[t]{2}{*}{$\mathrm{O}$} & Liver & - & \pm Hep, +BD & $++\mathrm{Hep},+\mathrm{BD}$ & ++ & ++ \\
\hline & Colon & \pm & + & NT & + & \\
\hline \multirow{2}{*}{ O } & Liver & - & - & + Hep, \pm BD & ++ & ++ \\
\hline & Colon & $\stackrel{+}{+}+\mathrm{Hen}+\mathrm{BD}$ & + & NT & ++ & \\
\hline $\mathrm{O}$ & $\begin{array}{l}\text { Liver } \\
\text { Colon }\end{array}$ & $\begin{array}{l}+ \text { Hep, } \pm \text { BD } \\
+\end{array}$ & $\begin{array}{l}+ \text { Hep, BD } \\
+\end{array}$ & $\begin{array}{l}+++ \text { Hep, }+ \text { BD } \\
\text { NT }\end{array}$ & $\begin{array}{l}+ \\
\pm\end{array}$ & $\begin{array}{l}++ \\
+\end{array}$ \\
\hline \multirow[t]{2}{*}{$\mathrm{O}$} & Liver & + Hep, \pm BD & + & +++ Hep,+ BD & - & ++ \\
\hline & Colon & +Focal & + & NT & \pm & + Focal \\
\hline \multirow[t]{2}{*}{$\mathrm{O}$} & Liver & - Hep, \pm BD & + & NT & $\overline{+}+$ & +++ \\
\hline & Colon & + Focal & + & NT & + & + \\
\hline
\end{tabular}

$\mathrm{NT}=$ not tested $\mathrm{HF}=$ hepatic flexure; $\mathrm{AC}=$ ascending colon .
Figure 1: (A) Group O primary sclerosing cholangitis patient showing inappropriate staining of bile ducts with anti-A antibody. (B) Group O primary sclerosing cholangitis patient showing inappropriate staining of bile ducts (and hepatocytes) with anti-B antibody compared with negative control. $(C)$,

(D) Staining with anti-Lewis a antibody. In normal (C) and alcoholic biopsy tissues staining is mainly in small ducts and shows a luminal pattern, while in cholestatic disease such as primary biliary cirrhosis $(D)$ staining is mainly cytoplasmic and in small and large ducts.
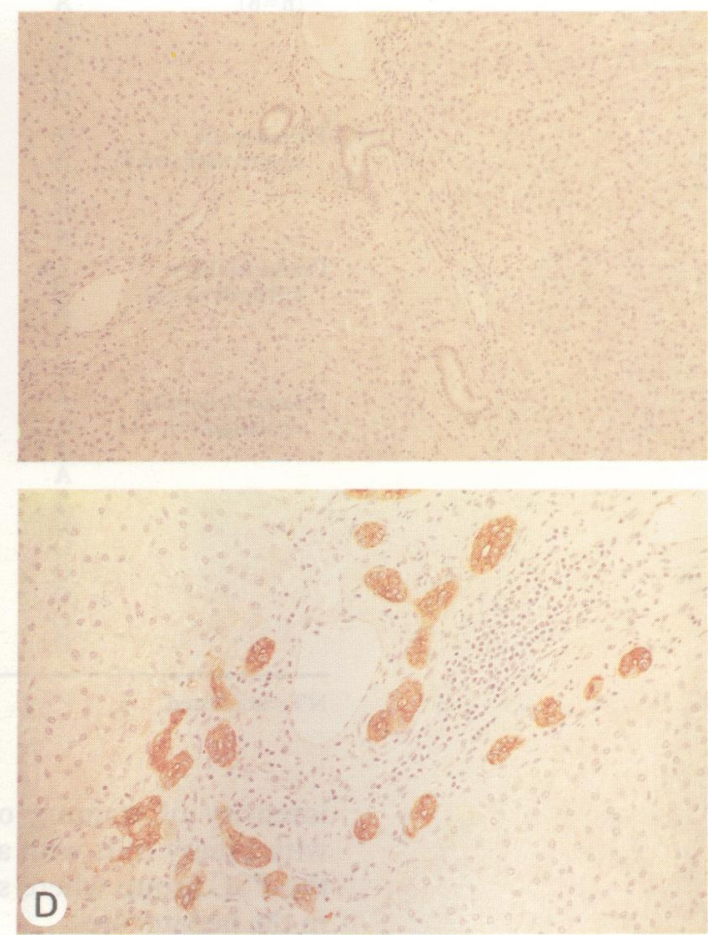

not been found previously. The inappropriate expression of $A$ and especially $B$ antigens in biliary epithelia in PSC is generally accompanied by a similar expression in hepatocytes (Fig 2). Our finding of increased staining with Lewis antibodies in cholestatic diseases with proliferation of bile ducts, agrees with that of Jinno et al. ${ }^{19}$ The uniform staining with anti-Lewis a throughout the colon, the proximal to distal gradient of anti-Lewis b staining, and the weaker staining with anti-Lewis $b$ than that observed in the biliary epithelium also agree with previous reports. ${ }^{1524}$

The biochemical pathways underlying precursor and product relationships in the $\mathrm{ABO}$ and Lewis blood group systems are complex and not completely understood. ${ }^{25}$ They are shown schematically in Figure 3.

It is possible that our finding of inappropriate staining with anti-B, and to a lesser extent anti$\mathrm{A}$, antibodies reflects non-specific binding of the antibodies to carbohydrate epitopes in biliary cells and hepatocytes, although this seems unlikely as it is not seen in other cells. In patients with blood group $A$, circulating anti-B antibody will bind to $B$ antigen in the liver and lead to decreased detection of this epitope by the mouse anti-B antibody. While we found increased expression of blood group B antigen in the 


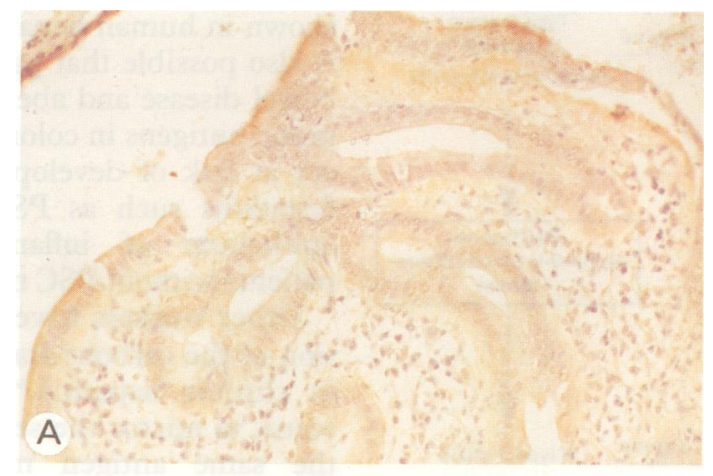

B

Figure 2: $(A)$ and $(B)$ Group $O$ patient with primary sclerosing cholangitis showing inappropriate staining of colonic epithelium with anti- $A(A)$ and anti-B $(B)$ antibodies.

patients studied, the levels might be even higher without this possible blocking effect.

Some of the antibodies we used were studied at the international workshop on blood group antibodies at Paris, 1987. Synthetic oligosacharides coupled to cristalline silica were used as solid immunoabsorbants to assess the degree of inhibition of antibody mediated agglutination. The B antibodies 16818-2 and BRIC 86 were inhibited by oligosaccharides involving a fucose attached to $\beta$ galactose, but not to linear disaccharides or to trisaccharides without the attached fucose. ${ }^{26}$
Similarly, one of the antibodies in the anti-A reagent, 15719, is not inhibited by the Forssman disaccharide or trisaccharide, involving $\mathrm{N}$ acetylgalactosamine instead of galactose in the $\beta$ position. ${ }^{27}$ These studies on the fine specificity of structures recognised by blood group antibodies do not completely rule out the possibility that a different epitope could be recognised by the antibodies in the livers and colons of PSC patients. A more likely explanation, however, is that there is a genuine increase in the activity of the enzymes producing the $A$ and $B$ antigens, namely alpha 1,3 $\mathrm{N}$-acetylgalactoseaminyltransferase and alpha 1,3 galactose transferase. Figure 3 shows how these enzymes both use the same substrate, the type $1 \mathrm{H}$ chain. A further enzyme, alpha 1,4 fucosyltransferase, can also act on this substrate to produce the Lewis $b$ antigen but acts on a different substrate to produce the Lewis a antigen. This study has shown that staining with anti-Lewis $a$ and $b$ antibodies is increased in patients with PSC and other cholestatic diseases compared with normal and alcoholic patients. This may represent either increased synthesis of the type 1 chain precursor or activation of the Le and $\mathrm{Se}$ genes. In addition, however, there is inappropriate staining with antibodies to $\mathrm{A}$ and $B$ antigens in PSC compared with other diseases. Whether there is upregulation of the genes that produce these antigens or merely a change in expression on the cell surface has not been investigated: in situ hybridisation should provide an answer to this question. In this context, a recent report ${ }^{28}$ that the well documented neoexpression of $\mathrm{ABH}$ and Lewis $\mathrm{b}$ antigens in colonic cancer is mediated by a higher expression of the enzyme alpha 2 fucosyltransferase may be relevant.

Why should the expression of these carbohydrate antigens in biliary epithelium be altered in PSC? Several reports show a change in these and related carbohydrate antigens in inflamma-

TABLE VI Staining patterns in normal and colitic controls

\begin{tabular}{|c|c|c|c|c|c|c|c|c|}
\hline \multirow{2}{*}{$\begin{array}{l}\text { Patient } \\
\text { No }\end{array}$} & \multirow{2}{*}{$\begin{array}{l}\text { Blood } \\
\text { group }\end{array}$} & \multirow[b]{2}{*}{ Diagnosis } & \multirow[b]{2}{*}{ Site } & \multicolumn{5}{|c|}{ Antibody staining } \\
\hline & & & & $A$ & $B$ & $H$ & $L e^{a}$ & $L e^{\mathrm{b}}$ \\
\hline 1 & $\mathrm{AB}$ & Normal & Descending colon & \pm Focal & - & \pm & + & + \\
\hline 2 & $\mathrm{O}$ & Normal & Descending colon & + & + & + & ++ & + \\
\hline 3 & A & Normal & Sigmoid & +Focal & - & \pm & + & \pm \\
\hline 4 & $\mathrm{~A}$ & Normal & Rectum & - & - & \pm Focal & + & \pm \\
\hline 5 & $\mathrm{O}$ & Normal & Right colon & - & - & \pm & + & - \\
\hline \multirow[t]{2}{*}{6} & $\mathrm{O}$ & Normal & Transverse & - & + & ++ & ++ & + \\
\hline & A & UC (sigmoid/rectum) & $\begin{array}{l}\text { Sigmoid } \\
\text { Splenic flexure }\end{array}$ & \pm & $\begin{array}{l}+ \\
+\end{array}$ & $\begin{array}{l}++ \\
-\end{array}$ & $\begin{array}{l}+ \\
+\end{array}$ & + \\
\hline 7 & & UC (sigmoid/rectum) & $\begin{array}{l}\text { Descending colon } \\
\text { Rectum }\end{array}$ & $\begin{array}{l}++ \\
\pm \text { Focal }\end{array}$ & $\begin{array}{l}++ \\
++ \\
\pm\end{array}$ & $\begin{array}{l}+++ \\
\pm\end{array}$ & $\begin{array}{l}+++ \\
+\end{array}$ & $\begin{array}{l}\text { +Luminal } \\
\text { 土Luminal }\end{array}$ \\
\hline 8 & $\mathrm{O}$ & $\begin{array}{l}\text { Crohn's } \\
\text { Rectum }\end{array}$ & $\begin{array}{l}\text { Sigmoid } \\
\text { Rectosigmoid } \\
\text { Ileum }\end{array}$ & $\begin{array}{l} \pm \text { Focal } \\
+ \text { Focal } \\
-\end{array}$ & $\begin{array}{l}+ \\
+ \text { Focal } \\
\pm \text { Focal }\end{array}$ & $\begin{array}{l}+ \\
+ \\
+\end{array}$ & $\begin{array}{l}+ \\
+ \text { Luminal } \\
+\end{array}$ & $\begin{array}{l}+ \\
\pm \text { Luminal } \\
+ \text { Focal }\end{array}$ \\
\hline 9 & A & UC (left) & $\begin{array}{l}\text { Ileum } \\
\text { Left colon }\end{array}$ & + & $\begin{array}{l}+ \\
\pm \text { Focal }\end{array}$ & $\begin{array}{l}+ \\
\pm\end{array}$ & $\begin{array}{l}++ \\
++\end{array}$ & $\begin{array}{l}++ \\
+\end{array}$ \\
\hline 10 & $\mathrm{O}$ & UC & Left colon & + Focal & + & $\overline{+}$ & + & + \\
\hline 11 & $\mathrm{O}$ & UC & Pouch & - & - & \pm & + Luminal & - \\
\hline 12 & $\mathrm{O}$ & UC & Left colon & - & - & - & + & \pm \\
\hline 13 & A & Crohn's & Ileum & + & - & +Focal & + & ++ \\
\hline 14 & A & UC & Left colon & - & - & - & + & \pm \\
\hline 15 & A & UC (total) & Left colon & - & - & - & + & \pm \\
\hline 16 & O & Crohn's colitis & Ascending colon & - & - & - & + & + \\
\hline 17 & A & UC (total) & $\begin{array}{l}\text { Hepatic flexure } \\
\text { Sigmoid }\end{array}$ & $\begin{array}{l}+ \\
+\end{array}$ & $\begin{array}{c}- \\
-\end{array}$ & $\frac{ \pm}{+}$ & $\begin{array}{l}++ \\
++\end{array}$ & $\begin{array}{l}\text { + Luminal } \\
\pm \text { Luminal }\end{array}$ \\
\hline 18 & $\mathrm{O}$ & UC (total) & Descending colon & \pm & - & $\stackrel{-}{-}$ & + Luminal & $\begin{array}{l}\text { ILuminal } \\
\pm \text { Luminal }\end{array}$ \\
\hline 19 & O & UC (total) & Rectum & \pm & \pm & + & +++ & + \\
\hline 20 & A & Crohn's colitis & Ascending colon & + & - & \pm & + & \pm Luminal \\
\hline 21 & $\mathrm{O}$ & UC (total) & Rectum & - & - & & & +Luminal \\
\hline 22 & $\mathrm{O}$ & UC (total) & Descending colon & +Focal & +Focal & +Focal & +++ & \\
\hline 23 & A & UC (total) & Descending colon & \pm Focal & $+($ Dysplasia $)$ & + & +Focal & +Focal \\
\hline 24 & A & UC (total) & Ascending colon & & - & - & + & +Focal \\
\hline
\end{tabular}




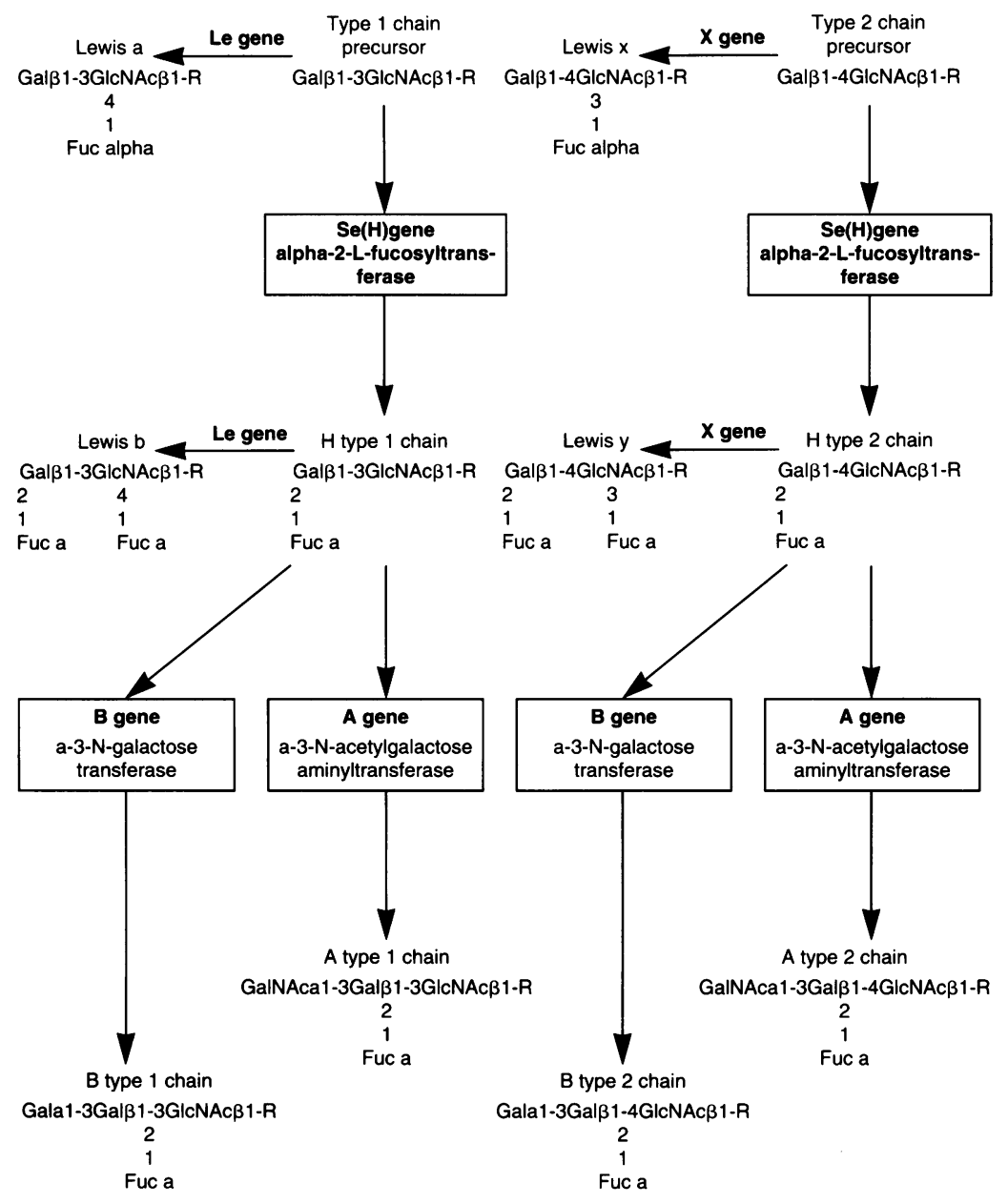

Le gene=alpha-4-L-fucosyltransferase

$X$ gene $=$ alpha-3-L-fucosyltransferase

Figure 3: Biosynthetic pathways in $A B H$ and Lewis antigen systems.

tory bowel disease. ${ }^{1729-31}$ They have been shown to have a characteristic temporal and regional expression in the human embryonic and fetal colon. ${ }^{2432}$ In the adult colon $\mathrm{A}, \mathrm{B}, \mathrm{H}$, and $\mathrm{Le}^{\mathrm{b}}$ disappear from the distal colon but persist in the proximal colon, ${ }^{33}$ while $\mathrm{Le}^{\mathrm{a}}$ is expressed uniformly throughout the colon. ${ }^{15}$ In cancer, these antigens may reappear in tumours derived from epithelial cells that expressed the antigen only during fetal development, or they may disappear in tumours arising from epithelial cells that normally express the antigen. They are therefore classed as oncofetal antigens. A recent study ${ }^{17}$ found that 32 of $51(63 \%)$ patients with ulcerative colitis showed some alteration of $\mathrm{ABO}$ expression, either re-expression or deletion. Incompatible $\mathrm{ABO}$ expression, although seen in only $6 \%$ of patients, seemed to be associated with dysplasia or cancer somewhere in the colon. This raises the question of whether the high incidence of incompatible blood group antigen expression in PSC may be a marker for developing dysplasia and malignancy in the biliary tract, bearing in mind the well established association between PSC and cholangiocarcinoma. Neoexpression of $\mathrm{ABH}$ and Lewis blood group antigens had been shown in human hepatocellular carcinomas. ${ }^{16}$ It is also possible that patients with inflammatory bowel disease and aberrant expression of blood group antigens in colonic and biliary epithelium are at risk of developing extraintestinal manifestations such as PSC. To test this, biliary epithelium of inflammatory bowel disease patients without PSC needs to be examined.

Other workers have shown increased expression of the carbohydrate antigen sialyl Lewis X in chronic hepatitis, ${ }^{34}$ with an intensity that seems to mirror the severity of the disease, and the same antigen may be associated with tumour. ${ }^{35}$ Sialyl Lewis $\mathrm{X}$ is in fact an isomer of sialylated Lewis a, except that the terminal disaccharide of the precursor molecule has a different structure (class 2). The biosynthesis of type 2 chains seems to be regulated differently to type 1 chains, however, because Lewis $\mathrm{X}$, the type 2 isomer of Lewis a, is not present to any extent in normal rectum. Thus, it may be the enzymes that work on the synthesis of the type 2 chain core structure that are involved in the abnormal expression of sialyl Lewis X..$^{28}$

We have shown that there is inappropriate staining with antibodies to carbohydrate blood group antigens in both biliary and colonic epithelium of patients with PSC compared with normal and disease controls. Other reports also suggest that in this disease there are circulating antibodies against antigens common to biliary and colonic epithelia. ${ }^{136}$ Given the presence of circulating antibodies in at least some of our patients (for example anti-A and anti-B in blood group $\mathrm{O}$ patients) this study raises the question of whether a change in cell surface antigens, presumably in the form of one or more carbohydrate epitopes affecting both colon and liver, plays a part in the pathogenesis of this condition.

1 Chapman RWG, Arborgh BAM, Rhodes JM, Summerfield JA, Dick R, Scheuer PJ, et al. Primary sclerosing cholangitis: a review of its clinical features, cholangiography and hepatic histology. Gut 1980; 21: 870-7.

2 Wiesner RH, LaRusso NF. Clinicopathologic features of the syndrome of primary sclerosing cholangitis. Gastroenterology 1980; 79 (2): 200-6

3 Chapman RW, Varghese Z, Gaul R, Patel G, Kokinon N Sherlock S. Association of primary sclerosing cholangitis with HLA-B8. Gut 1983; 24: 38-41.

4 Schrumpf E, Fausa O, Forre O, Dobloug JH, Ritland S, Thorsby E. HLA antigens and immunoregulatory T cells in Thorsby E. HLA antigens and immunoregulatory T cells in
ulcerative colitis associated with hepatobiliary disease. Ucand $\mathcal{T}$ Gastroenterol. 1982; 17: 187-91.

5 Lindor KD, Wiesner RH, Katzmann JA, LaRusso NF, Beaver SJ. Lymphocyte subsets in primary sclerosing
B. cholangitis. Dig Dis Sci 1987; 32: 720-5.

6 Lindor KD, Wiesner RH, LaRusso NF, Homburger HA Enhanced autoreactivity of $T$ lymphocytes in primary sclerosing cholangitis. Hepatology 1987; 7: 844-8.

7 Chapman RW, Kelly PMA, Heryet A, Jewell DP, Fleming KA. Expression of HLA DR antigens on bile duct epithelium in primary sclerosing cholangitis. Gut 1988; 29 : 422-7.

8 Whiteside TL, Lasky S, Si L, Van Thiel DH. Immunologic analysis of mononuclear cells in liver tissues and blood of patients with primary sclerosing cholangitis. Hepatology patients with prime

9 Bodenheimer HC Jr, LaRusso NF, Thayer WR, Charland C, Staples $\mathrm{Pj}$, Ludwig J. Elevated circulating immune complexes in primary sclerosing cholangitis. Hepatology complexes in $1983 ; 3: 150-4$.

10 Minuk GY, Angus M, Brickman CM, Lawley TJ, Frank MM, Hoofnagle JA, et al. Abnormal clearance of immune complexes from the circulation of patients with primary sclerosing cholangitis. Gastroenterology 1985; 88: 166-70.

11 Brinch L, Teisberg P, Schrumpf E, Akesson I. The in vivo metabolism of $\mathrm{C} 3$ in hepatobiliary disease associated with ulcerative colitis. Scand $\mathcal{F}$ Gastroenterology 1982; 17: 523-7.

12 Chapman RW, Cottone M, Selby WS, Shepherd HA, Sherlock S, Jewell DP. Serum autoantibodies, ulcerative colitis and primary sclerosing cholangitis. Gut 1986; 27: 8691 . 
13 Snook J, Chapman RW, Fleming K, Jewell DP. Antineutrophil nuclear antibody in inflammatory bowel disease neutrophil nuclear antibody in inflammatory bowel diseas

14 La Russo NF, Wiesner RH, Ludwig J, MacCarty RL. Current concepts: primary sclerosing cholangitis. $N$ Engl $\mathcal{F ~ M e d ~}$ 1984; 310: 899-903.

15 Ernst C, Atkinson B, Wysocka M, Blaszczyk M, Herlyn M, Sears $\mathrm{H}$, et al. Monoclonal localisation of Lewis antigens in fixed tissue. Lab Invest 1984; 50 (4): $394-400$.

16 Okada Y, Arima T, Togawa K, Nagashima $H$, Jinno $K$, Moriwaki S, et al. Neoexpression of ABH and Lewis blood group antigens in human hepatocellular carcinomas. $f N C I$ 1987; 78: 19-28.

17 Itzkowitz SH, Yuan M, Hanauer S, Goldenberg A, Kim YS Cancer associated alterations in blood group expression in ulcerative colitis. Gastroenterology 1988; 94 (5): A202.

18 Okada Y, Jinno K, Moriwaki S, Shimoe T, Tsuji T, Murkami $\mathrm{M}$, et al. Blood group antigens in the intrahepatic biliary $M$, et al. Blood group antigens in the intrahepatic biliary
tree. 1. Distribution in the normal liver. $\mathcal{F}$ Hepatol 1988; 6: tree. 1 .

19 Jinno K, Moriwaki S, Govindarajan S, Okada Y, Tsuji T. Blood group antigens in the intrahepatic biliary tree. II Type 1 chain $\mathrm{N}$-acetyllactosamine-related carbohydrate antigen in the proliferated bile ductules. F Hepatol 1989; 8: 330-7.

20 Ludwig J, LaRusso NF, Wiesner RH. Primary sclerosin cholangitis. Contemp Issues in Surgical Pathology 1986; 8: 193-213.

21 Leray G, Deugnier Y, Jouanolle A, Lehry D, Bretagne J, Campion J, et al. Biochemical aspects of $\alpha$-L-fucosidase in hepatocellular carcinoma. Hepatology 1989; 9:249-52.

22 Hansen PCG, Jackson GDF. Movement of IgM antibody from blood to bile in rats. Hepatology 1991; 14: 518-22.

23 Marshall JS, Green AM, Pensky J, Williams S, Zinn A Carlson DM. Measurement of circulating desialylated glycoproteins and corellation with hepatocellular damage. f Clin Inv 1974; 54: 555-62.

24 Szulman AE. The histological distribution of blood substances in man disclosed by immunofluorescence. $\mathcal{F}$ Exp Med 1964; 119: 503-15

25 Oriol R, Le Pendu J, Mollicone R. Genetics of ABO, H Lewis, $\mathrm{X}$ and related antigens. Vox Sanguis 1986; 51 : 161-
26 Mollicone R, Gane P, Rouger P, Oriol R. Inhibition on haemagglutination with synsorbs and salivas of anti-B and haemagglutination with synsorbs and salivas of anti-B and anti-AB monoclonal antibodies. Revue Française de
Transfusion et Immuno-Hématologie 1987; XXX (5): 579-87.

27 Gane P, Mollicone R, Rouger P, Oriol R. Inhibition of haemagglutination with synsorbs and salivas of anti-A monoclonal antibodies. Revue Française de Transfusion et Immuno-Hématologie 1987; XXX (5): 435-442.

28 Orntoft TF, Greenwell P, Clausen H, Watkins WM. Regulation of the oncodevelopmental expression of type 1 chain $\mathrm{ABH}$ and Lewis b blood group antigens in human colon by alpha 2-L fucosylation. Gut 1991; 32: 287-93.

29 Podolsky DK, Isselbacher KJ. Glycoprotein composition of colonic mucosa - specific alterations in ulcerative colitis. Gastroenterology 1984; 87: 991-8.

30 Rhodes JM, Black R, Patel P, Savage A. Carcinoma-type mucus abnormalities in ulcerative colitis and Crohn's disease mucus abnormalities in ulcerative colitis and Crohn's disease

31 Boland CR, Lance P, Levin B, Riddell RH, Kim YS. Abnormal goblet cell glycoconjugates in rectal biopsies associated with an increased risk of neoplasia in patients with ulcerative colitis: early results of a prospective study. Gut 1984; 25: 1364-71.

32 Du Bois AM. The embryonic liver. In: Rouiller $\mathrm{CH}$, ed. The Liver. Vol 1. Academic Press, New York: 1963; 1-16.

33 Szulman AE. The histological distribution of blood group substances A and B in man. F Exp Med 1960; 111: 785-80.

34 Okada Y, Usumoto R, Muguruma M, Shimoe T, Sunayama $\mathrm{T}$, Yamada $\mathrm{G}$, et al. The hepatocellular expression of a carbohydrate antigen 'sialyl Lewis X' in chronic hepatitis. A nove histological marker for active hepatic necroinflammanove histological marker for active
tion. $\mathcal{F}$ Hepatol $1990 ; 10$ (1): $1-7$.

35 Fukushima $K$, Hirota M, Terasaki P, Wakisaka A, Togashi $\mathrm{H}$, Chia D, et al. Characterisation of Sialosylated Lewis X as a new tumour associated antigen. Cancer Res 1984; 44: 5279 85.

36 Das KM, Jeffers L, Squillante L, Hyder S, Reddy R, Schiffe $\mathrm{H}$, et al. The presence of circulating antibodies in patients with sclerosing cholangitis against an epitope on $\mathrm{Mr} 40000$ protein shared by colon and bile duct epithelial cells. Gastroenterology 1989; 96: A590. 